This is an Accepted Manuscript of an article published in: Nature Geoscience (Published online 31 July 2017)

doi: https://doi.org/10.1038/ngeo3000

\title{
Tidal controls on river delta morphology
}

A.J.F. Hoitink ${ }^{1}$, Z.B. Wang ${ }^{2,3}$, B. Vermeulen ${ }^{1,4}$, Y. Huismans ${ }^{5}$ and K. Kästner ${ }^{1}$

${ }^{1}$ Hydrology and Quantitative Water Management Group,

Department of Environmental Sciences, Wageningen University and Research, The Netherlands

${ }^{2}$ Department of Hydraulic Enigneering, Faculty of Civil Engineering and Geosciences, Delft University of Technology, The Netherlands

${ }^{3}$ Marine and Coastal Systems Department, Deltares, The Netherlands

${ }^{4}$ Marine and Fluvial Systems, Department of Water Engineering and Management, Faculty of Engineering Technology, University of Twente, The Netherlands 
${ }^{5}$ River Dynamics and Inland Shipping Department, Deltares, The Netherlands

June 29, 2017 


\section{Abstract}

River delta degradation has been caused by extraction of natural resources, sediment retention by reservoirs, and sea-level rise. Despite global concerns about these issues, human activity in the world's largest deltas intensifies. Harbour development, construction of flood defences, sand mining and land reclamation emerge as key contemporary factors that exert an impact on delta morphology. Tides interacting with river discharge can play a crucial role in the morphodynamic development of delta channels under pressure. Emerging insights into tidal controls on river delta morphology suggest that - despite the active morphodynamics in tidal channels and mouthbar regions - tidal motion acts to stabilize delta morphology at the landscape scale under the condition that sediment import during low flows largely balances sediment export during high flows. Distributary channels subject to tides show lower migration rates and are less easily flooded by the river because of opposing nonlinear interactions between river discharge and the tide that lead to flow changes within channels and a more uniform distribution of discharge across channels. Sediment depletion and rigorous human interventions in deltas, including storm surge defence works, disrupt the dynamic morphological equilibrium and can lead to erosion and severe scour at the channel bed, even decades after an intervention. 


\section{Introduction}

River deltas are landforms subject to the dynamic forcing by terrestrial input of water and sediment. With the exception of lacustrine deltas, located where a river debouches in a lake, most river deltas are also exposed to marine processes generating tides, wind waves, storm surges and mean sea-level variations. Human activity and the impacts of climate change on river discharge and mean sea-level cause many deltas to be in a state of rapid transition, showcasting the Anthropocene era $^{1}$. Worldwide, deltas are sinking as a result of the extraction of water, oil and gas from the subsurface ${ }^{2}$. Embankment of delta channels and the construction of dams in the hinterland prevent natural aggradation of delta plains, which could mitigate delta lowering ${ }^{3,4,5}$. Herein, a delta plain is defined as the region bounded by the delta coastline and the landward limit where tides have become extinct. Awareness of the associated flood risk leads to the building of storm surge barriers and flood adaptation measures, rather than human abandonment. Even in flood prone coastal environments, such as the Rhine-Meuse Delta in The Netherlands, the Pearl Delta in China and the Ganges-Brahmaputra Delta in Bangadesh, substantial land reclamation occurs, navigation channels are deepened to allow larger vessels, and sand mining takes place to collect building material ${ }^{6,7,8}$. Harbour development and the need to transfer the river discharge to the coastal ocean prevent the complete closure of deltas. Therefore, even in strongly human-controlled 
deltas, marine influences such as tides penetrate into the channel networks behind sea defense structures, and act to reshape the delta morphology.

In pristine environments, delta planform characteristics reflect processes dominating channel network evolution over the past six to eight thousand years ${ }^{1}$. Delta channel topology encrypts information about sediment composition and the relative importance of river dynamics, tides and waves. Deltas need centuries rather than decades to adapt to rapid human induced change. Consequently, a mismatch may occur between contemporary delta morphology and the ongoing sedimentary processes. Due to sediment depletion and relative sea-level rise, deltas can become overrun by marine processes. When wave forcing dominates over tides, the delta retreat in response to sediment depletion can be qualitatively estimated, based on the ratio of fluvial sediment discharge and the maximum possible wave-driven sediment transport along the coast ${ }^{9}$. When tides dominate over wave forcing, the development of a delta under reduced fluvial sediment input is complicated by the various ways in which tides interact with the river discharge ${ }^{10}$. Here we review recent insights into tidal controls on river delta morphology, discuss morphodynamic modelling approaches, and offer a view on the lagged response of deltas to human activity. 


\section{Tidal fingerprints on deltas}

Tides add complexity to delta formation, by modulating the river flow in a transition zone where an upstream fluvial regime merges into a marine environment ${ }^{11,12}$. A tide-influenced delta landscape is characterized by elongated islands separating the distributary channels, and a coastline showing high rugosity ${ }^{13,14,15}$. The Ganges-Brahmaputra-Jamuna (GBJ) Delta can be viewed as the world's most extensive tide-influenced delta, and has recently been subject to a systematic planform analysis ${ }^{16}$. The tidal region of the GBJ delta is characterized by high channel density, absence of oxbow lakes and a small island shape factor, defined as the ratio of wetted perimeter and the square root of island area. The islands within the tide-influenced region show smooth boundaries compared to interdistributary islands in the fluvial dominated remainder of the delta. Research in the Fly River Delta revealed that the percentage of the delta plain covered by islands, i.e. the inverse of channel density, is related to peak tidal flow velocities ${ }^{17}$. Larger islands are associated with a decrease in tidal discharge amplitudes and related bed shear stresses, indicative for a reduced erosional power.

The delta planform transition from river-dominated to tide-dominated reaches is generally interpreted to be sharp rather than gradual ${ }^{16,18}$. In the tide-dominated part, rectilinear or mildly curved distributary channels may coexist with sinuous tidal channels, which are termed dead-end if they have a single connection to the 
channel network ${ }^{19}$. In dead-end tidal meanders, width converges and sinuosity increases landward. Vegetation and the presence of cohesive sediment in the soil tend to promote channel sinuosity ${ }^{20,21,22}$. In strongly depositional environments such as the Skagit River Delta, mid-channel marsh islands form at the junctions between distributaries and blind tidal meanders ${ }^{19}$. The gap between the island and the mainland narrows and subsequently closes at its upstream side, such that the remaining part becomes an extension of the blind tidal channel, featuring a right-angled bend. Interference between distributary channels and tidal channels can also be observed in the Mahakam Delta planform, which was interpreted using hydrodynamic model simulations of the distributary channel network (Fig. 1) $23,24,25$. A break in width and depth development along the distributaries, which splits the delta into river- and tide-dominated parts, coincides with a break in the ratio between tidal to fluvial discharges ${ }^{25}$. Results from facies successions confirm tidal dominance in the coastal fringe of the Mahakam Delta ${ }^{26}$. Beyond regions of tidal dominance in deltas, the tidal motion may still exert a significant influence on channel morphology. The width-to-depth ratio can increase up until the tidal limit, where the flow regime becomes fully fluvial ${ }^{18,27,28,29}$.

[Figure 1 about here.]

Tides exert an influence on the processes forming mouth bars, which may evolve into interdistributary delta plains ${ }^{30,31}$. The tidal controls on delta plain formation 
have been analysed from distributed process-based morphodynamic models adopting a schematized tidal motion ${ }^{15,32,33}$. In river-dominated deltas subject to weak tides, there is a continuous outflow at the mouths of the distributaries. Only outside the jet region, flow reversal occurs between ebb and flood. At the initial stages of delta formation in unidirectional flow, distributaries may form by incision in a coastal deposit at low tide, while slightly aggrading during flood stages ${ }^{15}$. The ebb tide reinforces the jet-like outflow of the river discharge, leading to lengthening of the levees and elongated channels ${ }^{15}$ and comparatively wide mouth bars ${ }^{32,34}$. Tidal oscillations favour flow bifurcation and the formation of a central mouth deposit $^{32}$, by steering the ebb flow towards the flanks of the bar. In case of stronger tides, the tidal flow amplitudes in the distributaries typically exceed the river flow, and the transition from flow reversal to unidirectional flow occurs inside the delta. Then, the ebb jet and reversed flood flow inhibit the formation of a central bar. This results in the formation of mouth bars on opposite sides of a central channel, creating a trifurcation such as visible in the Suwanee Delta, the Kapuas Delta and the Fly Delta (Fig. 2).

[Figure 2 about here.]

Focussing on the underwater morphology, tide-dominated deltas are characterized by a clinoform along the coastal boundary, defined as a sedimentary deposit with a sigmoidal cross-profile of the bed ${ }^{35}$. Across the clinothem, large amounts of 
heterolithic mud can be found ${ }^{35}$. Tidal distributaries debouching above the topset are typically composed of fine sands, being the terminal channels of a downstream fining river with the associated alluvial bed morphology. Active channels become shallower in the final sections, which relates to the presence of mouth bar deposits. Abandoned channels typically show a systematical deepening trend towards the river mouth. Few studies have explicitly addressed the bedform characteristics in tidal distributaries. Generally, in coastal settings with reversing tidal currents, the dune orientation is quasi-stable towards the dominant flow direction ${ }^{36,37,38}$. This was also observed in the tidal river feeding the tide-dominated Berau Delta, where dunes were found to be higher than what could be predicted for a nontidal river with the same tide-averaged flow and sediment composition ${ }^{39}$. In estuarine environments, the slope of the lee side of dunes is generally low-angled, causing dunes to be more symmetrical ${ }^{40,41}$, which may be attributed to the presence of clay rather than to the tidal motion ${ }^{42}$. Recent laboratory experiments show that bedform dimensions are directly related to clay content: increasing levels of clay content result in progressively smaller bedforms, with reduced height, length, and steepness $^{43}$. Dune properties in tide-dominated deltas are expected to have a lagged response to flow variation, and to be dependent on clay content. 


\section{Dynamic morphological equilibrium}

When the river input and tidal forcing averaged over a seasonal cycle are quasi steady, channels in a tide-influenced delta can evolve towards a near-equilibrium morphology. The earliest empirical evidence for the existence of a stable morphological equilibrium in tidal regions was obtained for tidal inlets in the USA, showing a high correlation between the tidal prism $P$ and the cross-section area $A^{44,45}$. Subsequent studies have confirmed the general validity of such a relationship, and its dependence on geological setting ${ }^{46,47,48}$. The $P$ - $A$ relationship is applicable at any location along the length of a single tidal channel, as was evidenced by numerical modelling studies ${ }^{27,49,50}$ and laboratory experiments ${ }^{51,52}$. Several alternative equilibrium relationships have been proposed, seeking scaling relations for planimetric area and the volume of a tidal basin ${ }^{48}$, channel hypsometry ${ }^{53,54,55}$, and the volume of an ebb-tidal delta in tidal inlets ${ }^{56}$. Simple, conceptual models can excel in identifying equilibrium states, and determining their stability ${ }^{11,57}$.

Applying results obtained for tidal inlets, salt marshes and single-thread tidal channels to branching delta channels is hampered by the lack of a firm theoretical basis for many of the existing empirical relations ${ }^{58}$. In addition, a delta subject to sediment accumulation and sea-level oscillation is by definition out of equilibrium, and different parts of the delta can display contrasting equilibrium or disequilibrium states. Yet with an a priori choice of the temporal and spatial scales over 
which the equilibrium is analysed, the equilibrium concept can have practical use in analyzing delta stability ${ }^{58}$. Adopting the spatial scale of the delta as a whole, and a time scale of several decades, delta growth can be neglected and sea level be considered constant.

A formal equilibrium for tidal channel morphology has only been found adopting rigorous simplifications, from one-dimensional analytical or numerical models $^{59,60}$. These idealized models are of conceptual relevance and provide a basic understanding about how tides increase the tide-average sediment transport capacity in case of uniform sediment. During low river discharge, tidal channels are typically flood-dominant, importing sediment from the mouth bar region. During high river discharge, sediment export prevails, caused by the higher sediment transport capacity, tidal attenuation, and reduced tidal deformation in larger water depths. In case of a near-equilibrium, sediment import during low flows balances sediment export during high flow over a seasonal cycle (Box 1).

[Figure 3 about here.]

Grain size variations and the presence of intertidal flats are key factors ignored in the simplified view on tide-dominated deltas, sketched in Box 1. Grain sizes become smaller towards the coast, as a result of downstream fining ${ }^{29}$. Flow velocities tend to decrease from the upstream river reaches where the bed slope is high towards the distributary channels across the delta plain. As a consequence 
of these trends, wash-load in the upstream reaches of the river becomes the bed material controlling morphological change in the downstream reaches, which is impossible to represent with uniform sediment. The mud fraction can play a key role in the morphological development of deltas ${ }^{15,61}$. Failing to represent intertidal flats leads to unrealistically low flow velocities ${ }^{62}$, especially when the fluvial input at the landward end is small. Existing two-dimensional (2D) models are still incapable of simulating the evolution of tidal deltas up to the point that an observed delta planform can be reproduced, but the state-of-the-art models do adequately predict characteristic channel-shoal patterns within a predefined modeling domain ${ }^{63,64,65,66,67,68}$, as illustrated in Fig. 3. These models typically simulate bedload rather than suspended load sediment transport, which likely affects the number and shape of distributary channels. Analytical studies addressing 2D developments are scarce, and fundamental understanding of how 2D channel-shoal patterns form often applies best to isolated channel-shoal systems ${ }^{69}$. Long-term morphodynamic model runs rarely converge to a quasi-steady channel morphology.

The lack of a theoretical basis for the concept of morphological equilibrium is a serious obstruction in modelling tide-dominated deltas. Morphological simulations starting with a measured bathymetry as an initial condition generally suffer from substantial spin-up phenomena, because of inconsistencies between the initial condition, the simplifications used to generate boundary conditions, and the 
complexity reduction approaches inherent to the adopted model. These spin-up effects in delta environments may last for decades, because of the long characteristic timescales for morphological evolution in alluvial domains with small bed slopes. The latter follows from a classical diffusion-type bed evolution equation ${ }^{70,71}$, which does not account for tides, waves and storm surges. These factors will amplify the dynamics, but do not reduce the spin-up time in morphodynamic simulations. This is in contrast to tidal hydrodynamic modelling, in which the spin-up period is limited to hours. For confined environments and under quasi-steady forcing conditions, the performance of morphological models increases after the decades of spin-up ${ }^{72}$. The simplified representation of the tide can be an important cause of the long spin-up time. The tidal schematisation is often based on considerations of the residual sediment transport. For cases with negligible residual flow velocity, a common assumption is that the tide can be adequately represented by the principal lunar semidiurnal tide, $\mathrm{M}_{2}$, and its overtides $\mathrm{M}_{4}$ and $\mathrm{M}_{6}{ }^{73}$. Recently, awareness has grown that the use of such a simplified or representative tide cannot be justified, because of multiple tidal asymmetries and the non-negligible residual flow governed by the river discharge ${ }^{74,75}$.

While closing the gap between the empirical knowledge and the process-based morphodynamic models is a major challenge for fundamental research ${ }^{76}$, hybrid approaches exist that combine empirical relations for morphological equilibrium 
with a process-modelling framework in which the sediment balance equation is aggregated in space and time $77,78,79,80,81$. In aggregated models, the formulation of sediment exchange between the channel bed and the water column is crucial. The rate of erosion or deposition is coupled to the difference between the actual morphological state and local equilibrium conditions. The exchange formulation is such that the simulated morphological state converges to an equilibrium satisfying the prescribed empirical relations, so long as the external forcing remains steady. The aggregated models have proven to be effective in modelling long-term morphological development in tidal channels ${ }^{82,83}$ and tidal flats ${ }^{84}$ without spin-up limitations. There are no conceptual limitations to embed improved understanding of morphological equilibrium conditions under various geological constraints and forcing conditions in aggregated morphological models, offering potential for further applications in delta distributary channels.

\section{Stability, flood vulnerability and delta degra- \\ dation}

With negligible river input, distributaries in a tidal delta self-organize to uniformly redistribute the tidal prism across the entire delta system ${ }^{85}$. When a river merges into a tidal delta network of distributary channels, the distributary channels are 
often more stable than the upstream river reach, which is inferred from lower bank migration rates ${ }^{86}$. For example, in the Ganges-Brahmaputra Delta, channel migration rates in the upland fluvial fan are much higher than those in the lowland delta plain ${ }^{87}$. The sinuosity of tidal channels tends to reduce towards the coast ${ }^{88}$, which also holds for distributary channels strongly influenced by the tide. The sinuosity of lowland rivers is often directly coupled to channel migration ${ }^{89}$. In the fluvial to tidal transition zone, flow reversal reduces the point-bar push effect ${ }^{90}$, which is considered to be a key driver of meander migration ${ }^{91}$. The mean flow, being a plausible factor controlling bar migration and subsequent planform change, diminishes towards the coast as a result of systematic expansion of the channel width. A recent study of the Kapuas Delta shows how the width-to-depth ratio in the tide-dominated part of the delta plain increases towards the coast, which confirms theoretical studies ${ }^{69}$ and directly relates to bar dynamics ${ }^{92}$. Avulsion loops in the Kapuas gradually fill up, while the planform in the coastal region upstream of an active mouth bar system shows to be stable. A high river discharge partially occupies the space accommodating tidal discharges during low river discharge, and does not necessarily result in exceptionally strong flows in the delta channels. Compared with the fluvial regime, impacts of peak river flow on the banks of distributary channels are thus limited. Tidal channel networks may further be stabilized by the nonlinear interaction between river discharge and the 
tide, preventing closure of a smaller distributary channel by counteracting asymmetry in the division of discharge at bifurcations ${ }^{24,25}$. When a larger fraction of the discharge is allocated to the largest of two channels at a bifurcation, the setup created by the interaction between mean flow and the tidal motion in the larger channel increases the water level gradient in the smaller channel, redistributing the river discharge.

[Figure 4 about here.]

Deltas influenced by the tide can be less flood-prone than lowland areas upstream of the delta apex, as exemplified for the Ganges-Brahmaputra Delta and the Mekong Delta based on flood frequency maps ${ }^{93}$. Storm surge flooding forms a greater threat than peak river discharges. The Ganges-Brahmaputra coastal margin reveals how human embankment of a tidal landscape significantly amplifies flood vulnerability ${ }^{8}$. Natural parts of the physical environment of the GangesBrahmaputra Delta, which include the Sundarban mangrove forests, show to be relatively robust, with no major land loss nor conversion despite that the westcentral delta plain has been effectively cut off from fluvial sediment over the past several thousand years (Fig. 4). Sediment accretion during high tides and overwash events related to storm surges prevents the Sundarban forests from sinking. The flood resilience of these natural environments sharply contrasts with the sediment-starved, embanked islands used for agriculture, termed polders. Herein, 
flood resilience of a delta area is defined as the degree in which erosion is resisted during flooding. Multiple dike failures during Cyclone Aila in 2009 caused an inundation event lasting more than two years. Most bank failures occurred at the mouths of former tidal channels blocked by the embankments, where riverbank erosion had occurred in the decade before the storm ${ }^{8}$. Embankment of polders and reclaimed land characterizes many of the tidal delta plains in Western Europe and China. In the Rhine-Meuse Delta, virtually all intertidal areas have been impoldered, except for small-scale nature reserves (Fig. 4). In the Pearl River Delta, land reclamation is the most significant factor that progressively alters delta morphology, overwhelming the effects of subsidence and reduction of sediment supply ${ }^{7}$. Embankment of the intertidal areas adjacent to a tidal channel alters the relation between tidal prism and cross-section area, disrupting the morphological equilibrium that may be present prior to land reclamation ${ }^{94}$.

[Figure 5 about here.]

The disequilibrium between tidal prism and cross-section area in a delta subject to anthropogenic change can become manifest as the formation of scour holes (Fig. 5). Due to the heterogeneity of the delta subsoil lithology, which may consist of readily erodible sands interspersed with patches and layers of erosion resistant clay and peat ${ }^{95,96}$, incision is distributed unequally over the channel, resulting in scour holes. Recent developments in the Rhine-Meuse Delta show 
the progressive development of about 100 bathymetric depressions scanned during periodic multi-beam surveys ${ }^{97}$. These depressions are either relic features from an ancient bathymetry, a direct cause of erosion, or a combination of both. The tidal regime in the lower branches of the Rhine and Meuse has been altered by closure of the Haringvliet estuary in 1970 , which has caused strong channel incision ${ }^{98}$. The connecting channels between the dammed estuary and active northern branch subject to deepening for navigation (Figure 5) now convey a disproportional large tidal prism, as a consequence of tides propagating from the northern branch to the Haringvliet basin. The continuous growth and the emergence of new scour holes is likely influenced by the general incision after closure of the Haringvliet ${ }^{97}$. The interpretation of bathymetric change can be complicated by dredging and sand mining. In the Pearl River Delta, sand mining for construction purposes is considered the primary reason for channel bed degradation ${ }^{99}$. Similarly, sand mining is current practice in the Mekong Delta, where it forms the main cause of recent morphological changes leading to bank erosion ${ }^{100}$. In all the examples discussed above, the assessment of instability is largely qualitative and subjective. There is a need for quantitative metrics that can be used to objectively assess the degree of instability.

The evolution of an eroding tide-dominated delta is conceptually more complex than delta progradation, which can be understood from the pathways of sed- 
iment from river source to the sinks in the delta. Processes of compaction, mixing of sands with clay and the influence of peat layers complicate the prediction of erosion. Holocene channel bed reconstructions can be used to quantify erosion resistance and estimate the risk of scour, which can be seen as a first step towards the prediction of channel incision. Scour hole formation presents a challenge to existing models simulating the dynamic feedback between flow, sediment transport and morphology, as the flow in a bathymetric depression is typically strongly three-dimensional. This flow complexity invalidates the common assumption of a hydrostatic pressure distribution adopted in most morphodynamic models ${ }^{101}$. Channel incision amplifies the tidal motion and may amplify the import of finegrained coastal sediment, reinforcing a high turbidity regime peaking in an Estuarine Turbidity Maximum (ETM). In the context of dredging of navigation channels in deltas, ETMs have often been associated with sediment accretion, yet the link between ETMs and delta evolution at geological timescales has remained largely unexplored to date. For example, the Fly Delta accommodates an ETM ${ }^{102}$ that is ignored by a recent study that focused on long-term morphodynamics ${ }^{17,18}$. ETM dynamics is strongly dependent on density gradients at the fresh to salt water interface, which introduces another reason for a more advanced modelling approach. Anticipating the effects of sea-level rise, sediment depletion, the construction of storm surge barriers, and channel deepening on tide-dominated deltas calls for 
combining quantified erosion resistance from geological records with a new generation of morphodynamic models.

\section{Conclusion}

Tides can exert a strong control on delta morphology. Despite the active morphological processes in distributaries and mouth bar regions in tidal deltas ${ }^{15,32}$, recent research suggests that tides may act to stabilize the delta planform, provided that near-equilibrium conditions are prevalent at the landscape scale. The rates of meander migration in tidally-influenced distributary channels are relatively low ${ }^{87}$, which can be explained from the reversing flow reducing the point bar push effect ${ }^{90}$ held responsible for meander migration ${ }^{91}$. Tides can reduce the asymmetry in the division of discharge over distributary channels in deltas ${ }^{25,103}$. When a distributary splits into a larger and a smaller channels, the larger channel will be subject to stronger tides, and receive a larger share of the river discharge. The interaction between river discharge and the tidal motion may counteract the gradual abandonment of smaller channels, as often observed in river delta distributaries with limited tidal motion. Inside a delta, the river discharge does not often cause inundation, because the river flow attenuates the tide. With weaker tides, the channel capacity is sufficient to accommodate a high discharge, which may cause inundation in the upstream reaches, prior to reaching the delta. Flood frequency maps 
of the Mekong and Ganges-Brahmaputra catchments show that the tidal deltas in these catchments are less frequently flooded than the plains adjacent to the corresponding upstream river reaches ${ }^{93}$, which suggests that formative bankfull discharge conditions will also occur less frequently. Recent research in the Kapuas delta plain confirms that the distributary channel planform is more stable than the planform of the river that feeds the delta ${ }^{29}$. Human interventions in deltas, such as storm surge defenses, disrupt the dynamic delta equilibrium, which may result in severe scour as it is occurring in the Rhine-Meuse Delta ${ }^{98}$.

\section{Acknowledgments}

This study has been supported by the Netherlands Organization for Scientific Research (NWO), project 1022/01966/ALW, and by the Royal Netherlands Academy of Arts and Sciences (KNAW), project SPIN3-JRP-29. We thank Leicheng Guo (East China Normal University, Shanghai) for making available the images we used to prepare Figure 3. We appreciate the support of the Editor, Dr. Tamara Goldin, and three anonymous reviewers, who have helped improving this manuscript. 


\section{References}

[1] Renaud, F. G. et al. Tipping from the Holocene to the Anthropocene: how threatened are major world deltas? Current Opinion in Environmental Sustainability 5, 644-654 (2013).

[2] Syvitski, J. P. M. et al. Sinking deltas due to human activities. Nature Geoscience 2, 681-686 (2009).

[3] Paola, C. et al. Natural processes in delta restoration: Application to the Mississippi Delta. Annual Review of Marine Science 3, 67-91 (2011).

[4] Giosan, L., Constantinescu, S., Filip, F. \& Deng, B. Maintenance of large deltas through channelization: Nature vs. humans in the Danube delta. Anthropocene 1, 35-45 (2013).

[5] Giosan, L., Syvitski, J., Constantinescu, S. \& Day, J. Climate change: protect the world's deltas. Nature 516, 31-33 (2014).

[6] Vellinga, N. E., Hoitink, A. J. F., van der Vegt, M., Zhang, W. \& Hoekstra, P. Human impacts on tides overwhelm the effect of sea level rise on extreme water levels in the Rhine-Meuse delta. Coastal Engineering 90, 40-50 (2014).

[7] Zhang, W. et al. Morphological change in the Pearl River Delta, China. Marine Geology 363, 202-219 (2015). 
[8] Auerbach, L. W. et al. Flood risk of natural and embanked landscapes on the Ganges-Brahmaputra tidal delta plain. Nature Climate Change 5, 153-157 (2015).

[9] Nienhuis, J. H., Ashton, A. D. \& Giosan, L. What makes a delta wavedominated? Geology 43, 511-514 (2015).

[10] Hoitink, A. J. F. \& Jay, D. A. Tidal river dynamics: implications for deltas. Reviews of Geophysics 240-272 (2016).

[11] Fagherazzi, S. \& Overeem, I. Models of deltaic and inner continental shelf landform evolution. Annu. Rev. Earth Planet. Sci. 35, 685-715 (2007).

[12] Ashworth, P. J., Best, J. L. \& Parsons, D. R. Fluvial-Tidal Sedimentology, vol. 68 of Developments in Sedimentology (Elsevier, 2015).

[13] Galloway, W. E. Process framework for describing the morphologic and stratigraphic evolution of deltaic depositional systems (Houston Geological Society, 1975).

[14] Orton, G. J. \& Reading, H. G. Variability of deltaic processes in terms of sediment supply, with particular emphasis on grain size. Sedimentology 40, 475-512 (1993).

[15] Geleynse, N. et al. Controls on river delta formation; insights from numerical modelling. Earth and Planetary Science Letters 302, 217-226 (2011). 
[16] Passalacqua, P., Lanzoni, S., Paola, C. \& Rinaldo, A. Geomorphic signatures of deltaic processes and vegetation: The Ganges-Brahmaputra-Jamuna case study. Journal of Geophysical Research: Earth Surface 118, 1838-1849 (2013).

[17] Canestrelli, A., Fagherazzi, S., Defina, A. \& Lanzoni, S. Tidal hydrodynamics and erosional power in the Fly River delta, Papua New Guinea. Journal of Geophysical Research: Earth Surface 115 (2010).

[18] Canestrelli, A., Lanzoni, S. \& Fagherazzi, S. One-dimensional numerical modeling of the long-term morphodynamic evolution of a tidally-dominated estuary: The Lower Fly River (Papua New Guinea). Sedimentary Geology 301, 107-119 (2014).

[19] Hood, W. G. Tidal channel meander formation by depositional rather than erosional processes: examples from the prograding Skagit River Delta (Washington, USA). Earth Surface Processes and Landforms 35, 319-330 (2010).

[20] Garofalo, D. The influence of wetland vegetation on tidal stream channel migration and morphology. Estuaries 3, 258-270 (1980).

[21] Eisma, D. Intertidal deposits: river mouths, tidal flats, and coastal lagoons, vol. 16 of CRC Marine Science (CRC Press, 1998). 
[22] Hughes, Z. J. Tidal channels on tidal flats and marshes. In Principles of Tidal Sedimentology, 269-300 (Springer, 2012).

[23] De Brye, B. et al. Preliminary results of a finite-element, multi-scale model of the Mahakam Delta (Indonesia). Ocean Dynamics 61, 1107-1120 (2011).

[24] Sassi, M. G., Hoitink, A. J. F., de Brye, B., Vermeulen, B. \& Deleersnijder, E. Tidal impact on the division of river discharge over distributary channels in the Mahakam Delta. Ocean Dynamics 61, 2211-2228 (2011).

[25] Sassi, M. G., Hoitink, A. J. F., Brye, d. B. \& Deleersnijder, E. Downstream hydraulic geometry of a tidally influenced river delta. Journal of Geophysical Research: Earth Surface 117 (2012).

[26] Salahuddin \& Lambiase, J. J. Sediment dynamics and depositional systems of the Mahakam Delta, Indonesia: ongoing delta abandonment on a tidedominated coast. Journal of Sedimentary Research 83, 503-521 (2013).

[27] Guo, L., Van der Wegen, M., Roelvink, J. A. \& He, Q. The role of river flow and tidal asymmetry on 1-D estuarine morphodynamics. Journal of Geophysical Research: Earth Surface 119, 2315-2334 (2014).

[28] Gugliotta, M. et al. Process regime, salinity, morphological, and sedimentary trends along the fluvial to marine transition zone of the mixed-energy Mekong River delta, Vietnam. Continental Shelf Research (2017). 
[29] Kästner, K., Hoitink, A. J. F., Vermeulen, B., Geertsema, T. J. \& Ningsih, N. S. Distributary channels in the fluvial to tidal transition zone. Journal of Geophysical Research: Earth Surface 122, 696-710 (2017). URL http://dx.doi.org/10.1002/2016JF004075.

[30] Tamura, T. et al. Origin and evolution of interdistributary delta plains; insights from mekong river delta. Geology 40, 303-306 (2012).

[31] Korus, J. T. \& Fielding, C. R. Asymmetry in Holocene river deltas: Patterns, controls, and stratigraphic effects. Earth-Science Reviews 150, 219$242(2015)$.

[32] Leonardi, N., Canestrelli, A., Sun, T. \& Fagherazzi, S. Effect of tides on mouth bar morphology and hydrodynamics. Journal of Geophysical Research: Oceans 118, 4169-4183 (2013).

[33] Leonardi, N., Sun, T. \& Fagherazzi, S. Modeling tidal bedding in distributary-mouth bars. Journal of Sedimentary Research 84, 499-512 (2014).

[34] Edmonds, D. A. \& Slingerland, R. L. Mechanics of river mouth bar formation: Implications for the morphodynamics of delta distributary networks. Journal of Geophysical Research: Earth Surface 112 (2007). 
[35] Goodbred Jr, S. L. \& Saito, Y. Tide-dominated deltas. In Principles of Tidal Sedimentology, 129-149 (Springer, 2012).

[36] Ernstsen, V. B. et al. Quantification of dune dynamics during a tidal cycle in an inlet channel of the Danish Wadden Sea. Geo-Marine Letters 26, 151-163 (2006).

[37] Lefebvre, A., Ernstsen, V. B. \& Winter, C. Influence of compound bedforms on hydraulic roughness in a tidal environment. Ocean Dynamics 61, 22012210 (2011).

[38] Kwoll, E., Becker, M. \& Winter, C. With or against the tide: The influence of bed form asymmetry on the formation of macroturbulence and suspended sediment patterns. Water Resources Research 50, 7800-7815 (2014).

[39] Hoitink, A. J. F., Buschman, F. A. \& Vermeulen, B. Continuous measurements of discharge from a horizontal acoustic Doppler current profiler in a tidal river. Water resources research 45 (2009).

[40] Bradley, R. W. et al. Flow and sediment suspension events over low-angle dunes: Fraser Estuary, Canada. Journal of Geophysical Research: Earth Surface 118, 1693-1709 (2013).

[41] Hendershot, M. L. et al. Response of low-angle dunes to variable flow. Sedimentology 63, 743-760 (2016). 
[42] Baas, J. H., Best, J. L. \& Peakall, J. Predicting bedforms and primary current stratification in cohesive mixtures of mud and sand. Journal of the Geological Society 173, 12-45 (2015).

[43] Schindler, R. J. et al. Sticky stuff: Redefining bedform prediction in modern and ancient environments. Geology 43, 399-402 (2015).

[44] O'Brien, M. P. Estuary tidal prisms related to entrance areas. Civil Engineering 1, 738-739 (1931).

[45] Jarrett, J. T. Tidal prism-inlet area relationships. Tech. Rep., DTIC Document (1976).

[46] Gerritsen, F. Morphological stability of inlets and tidal channels in the western Wadden Sea. In Dankers, N. M. J. A., Smit, C. J. \& Scholl, M. (eds.) Present and Future Conservation of the Wadden Sea: Proceedings of the 7th International Wadden Sea Symposium, Ameland, 151-160 (1992).

[47] Gao, S. \& Collins, M. Tidal inlet equilibrium, in relation to cross-sectional area and sediment transport patterns. Estuarine, Coastal and Shelf Science 38, 157-172 (1994).

[48] Townend, I. H. An examination of empirical stability relationships for UK estuaries. Journal of Coastal Research 1042-1053 (2005). 
[49] D'Alpaos, A., Lanzoni, S., Marani, M. \& Rinaldo, A. On the tidal prismchannel area relations. Journal of Geophysical Research: Earth Surface $\mathbf{1 1 5}$ (2010).

[50] Guo, L., Van der Wegen, M., Roelvink, D. J. A., Wang, Z. B. \& He, Q. Longterm, process-based morphodynamic modeling of a fluvio-deltaic system, part I: The role of river discharge. Continental Shelf Research 109, 95-111 (2015).

[51] Stefanon, L., Carniello, L., D’Alpaos, A. \& Lanzoni, S. Experimental analysis of tidal network growth and development. Continental Shelf Research $\mathbf{3 0}$, 950-962 (2010).

[52] Zhou, Z. et al. A comparative study of physical and numerical modeling of tidal network ontogeny. Journal of Geophysical Research: Earth Surface 119, 892-912 (2014).

[53] Boon, J. D. \& Byrne, R. J. On basin hypsometry and the morphodynamic response of coastal inlet systems. Marine Geology 40, 27-48 (1981).

[54] Wang, Z. B., Jeuken, M. C. J. L., Gerritsen, H., De Vriend, H. J. \& Kornman, B. A. Morphology and asymmetry of the vertical tide in the Westerschelde estuary. Continental Shelf Research 22, 2599-2609 (2002).

[55] Townend, I. H. Hypsometry of estuaries, creeks and breached sea wall sites. 
In Proceedings of the Institution of Civil Engineers-Maritime Engineering, vol. 161, 23-32 (Thomas Telford Ltd, 2008).

[56] Walton, T. L. \& Adams, W. D. Capacity of inlet outer ears to store sand. Coastal Engineering Proceedings 1 (1976).

[57] Mariotti, G. \& Fagherazzi, S. Critical width of tidal flats triggers marsh collapse in the absence of sea-level rise. Proceedings of the national Academy of Sciences 110, 5353-5356 (2013).

[58] Zhou, Z. et al. Is morphodynamic equilibrium an oxymoron? Earth-Science Reviews 165, 257-267 (2016).

[59] Schuttelaars, H. M. \& Swart, H. E. d. Multiple morphodynamic equilibria in tidal embayments. Journal of Geophysical Research: Oceans 105, 2410524118 (2000).

[60] Bolla Pittaluga, M. et al. Where river and tide meet: The morphodynamic equilibrium of alluvial estuaries. Journal of Geophysical Research: Earth Surface 120, 75-94 (2015).

[61] Edmonds, D. A. \& Slingerland, R. L. Significant effect of sediment cohesion on delta morphology. Nature Geoscience 3, 105-109 (2010).

[62] Van Prooijen, B. C. \& Wang, Z. B. A 1D model for tides waves and fine 
sediment in short tidal basins - Application to the Wadden Sea. Ocean Dynamics 63, 1233-1248 (2013).

[63] Hibma, A., De Vriend, H. J. \& Stive, M. J. F. Numerical modelling of shoal pattern formation in well-mixed elongated estuaries. Estuarine, Coastal and Shelf Science 57, 981-991 (2003).

[64] Marciano, R., Wang, Z. B., Hibma, A., de Vriend, H. J. \& Defina, A. Modeling of channel patterns in short tidal basins. Journal of Geophysical Research: Earth Surface 110 (2005).

[65] Van der Wegen, M. \& Roelvink, J. A. Long-term morphodynamic evolution of a tidal embayment using a two-dimensional, process-based model. Journal of Geophysical Research: Oceans 113 (2008).

[66] Dastgheib, A., Roelvink, J. A. \& Wang, Z. B. Long-term process-based morphological modeling of the Marsdiep Tidal Basin. Marine Geology 256, 90-100 (2008).

[67] Van Maanen, B., Coco, G. \& Bryan, K. R. Modelling the effects of tidal range and initial bathymetry on the morphological evolution of tidal embayments. Geomorphology 191, 23-34 (2013).

[68] Luan, H. L., Ding, P. X., Wang, Z. B. \& Ge, J. Z. Process-based morphody- 
namic modeling of the Yangtze Estuary at a decadal timescale: Controls on estuarine evolution and future trends. Geomorphology 290, 347-364 (2017).

[69] Lanzoni, S. \& D'Alpaos, A. On funneling of tidal channels. Journal of Geophysical Research: Earth Surface 120, 433-452 (2015).

[70] De Vries, M. A morphological time-scale for rivers. In Proceedings of IAHR Congress, Sao Paulo (Brazil), vol. 2, 17-23 (1975).

[71] Di Silvio, G. \& Nones, M. Morphodynamic reaction of a schematic river to sediment input changes: Analytical approaches. Geomorphology 215, 74-82 (2014).

[72] Dam, G., Wegen, M., Labeur, R. J. \& Roelvink, J. A. Modeling centuries of estuarine morphodynamics in the Western Scheldt estuary. Geophysical Research Letters 43, 3839-3847 (2016).

[73] Van de Kreeke, J. \& Robaczewska, K. Tide-induced residual transport of coarse sediment; application to the Ems estuary. Netherlands Journal of Sea Research 31, 209-220 (1993).

[74] Chu, A., Wang, Z. B. \& de Vriend, H. J. Analysis on residual coarse sediment transport in estuaries. Estuarine, Coastal and Shelf Science 163, 194-205 (2015). 
[75] Guo, L., Van der Wegen, M., Wang, Z. B., Roelvink, D. \& He, Q. Exploring the impacts of multiple tidal constituents and varying river flow on long-term, large-scale estuarine morphodynamics by means of a 1-D model. Journal of Geophysical Research: Earth Surface 121, 1000-1022 (2016).

[76] Wang, Z. B. et al. Morphodynamics of the Wadden Sea and its barrier island system. Ocean $\&$ coastal management 68, 39-57 (2012).

[77] Stive, M. J. F., Capobianco, M., Wang, Z. B., Ruol, P. \& Buijsman, M. C. Physics of estuaries and coastal seas, chap. Morphodynamics of a tidal lagoon and the adjacent coast, 397-407 (Balkema Rotterdam, 1998).

[78] Fagherazzi, S. \& Furbish, D. J. On the shape and widening of salt marsh creeks. Journal of Geophysical Research: Oceans 106, 991-1003 (2001).

[79] Stive, M. J. F. \& Wang, Z. B. Morphodynamic modeling of tidal basins and coastal inlets. Elsevier oceanography series 67, 367-392 (2003).

[80] Spearman, J. R. . Regime modelling of morphology. In Dohmen-Janssen, C. M. \& Hulscher, S. J. M. H. (eds.) River, Coastal and Estuarine Morphodynamics, 171-178 (Taylor \& Francis, 2007).

[81] Townend, I. H., Wang, Z. B., Stive, M. J. F. \& Zhou, Z. Development and extension of an aggregated scale model: Part 1-Background to ASMITA. China Ocean Engineering 30, 483-504 (2016). 
[82] Townend, I. H., Wang, Z. B. \& Rees, J. G. Millennial to annual volume changes in the Humber Estuary. Proceedings of the Royal Society of London A: Mathematical, Physical and Engineering Sciences 463, 837-854 (2007).

[83] Wang, Z. B. \& Townend, I. H. Influence of the nodal tide on the morphological response of estuaries. Marine Geology 291, 73-82 (2012).

[84] Hu, Z., Wang, Z. B., Zitman, T. J., Stive, M. J. F. \& Bouma, T. J. Predicting long-term and short-term tidal flat morphodynamics using a dynamic equilibrium theory. Journal of Geophysical Research: Earth Surface 120, 1803-1823 (2015).

[85] Fagherazzi, S. Self-organization of tidal deltas. Proceedings of the National Academy of Sciences 105, 18692-18695 (2008).

[86] Dalrymple, R. W., Zaitlin, B. A. \& Boyd, R. Estuarine facies models: conceptual basis and stratigraphic implications: perspective. Journal of Sedimentary Research 62 (1992).

[87] Wilson, C. A. \& Goodbred Jr, S. L. Construction and maintenance of the ganges-brahmaputra-meghna delta: linking process, morphology, and stratigraphy. Annual review of marine science 7, 67-88 (2015).

[88] Marani, M., Lanzoni, S., Zandolin, D., Seminara, G. \& Rinaldo, A. Tidal meanders. Water Resources Research 38 (2002). 
[89] Furbish, D. J. River-bend curvature and migration: How are they related? Geology 16, 752-755 (1988).

[90] Keevil, C. E., Parsons, D. R., Keevil, G. M. \& Ainsley, M. Three-dimensional meander bend flow within the tidally influenced fluvial zone. Developments in Sedimentology 68, 127-148 (2015).

[91] Eke, E., Parker, G. \& Shimizu, Y. Numerical modeling of erosional and depositional bank processes in migrating river bends with self-formed width: Morphodynamics of bar push and bank pull. Journal of Geophysical Research: Earth Surface 119, 1455-1483 (2014).

[92] Seminara, G. \& Tubino, M. Sand bars in tidal channels. part 1. free bars. Journal of Fluid Mechanics 440, 49-74 (2001).

[93] Syvitski, J. P., Overeem, I., Brakenridge, G. R. \& Hannon, M. Floods, floodplains, delta plainsa satellite imaging approach. Sedimentary Geology 267, 1-14 (2012).

[94] Dai, Z., Fagherazzi, S., Mei, X., Chen, J. \& Meng, Y. Linking the infilling of the north branch in the changjiang (yangtze) estuary to anthropogenic activities from 1958 to 2013. Marine Geology 379, 1-12 (2016).

[95] Berendsen, H. \& Stouthamer, E. Late Weichselian and Holocene palaeo- 
geography of the Rhine-Meuse delta, The Netherlands. Palaeogeography, Palaeoclimatology, Palaeoecology 161, 311-335 (2000).

[96] Hijma, M. \& Cohen, K. Holocene transgression of the Rhine river mouth area, The Netherlands/Southern North Sea: palaeogeography and sequence stratigraphy. Sedimentology 58, 1453-1485 (2011).

[97] Huismans, Y., van Velzen, G., OMahoney, T., Hoffmans, G. \& Wiersma, A. Scour hole development in river beds with mixed sand-clay-peat stratigraphy. In 8th International Conference on Scour and Erosion (Technical Committee ISO/TC213, 2016). 12-15 September 2016.

[98] Sloff, K., Van Spijk, A., Stouthamer, E. \& Sieben, A. Understanding and managing the morphology of branches incising into sand-clay deposits in the dutch rhine delta. International Journal of Sediment Research 28, 127-138 (2013).

[99] Zhang, W., Ruan, X., Zheng, J., Zhu, Y. \& Wu, H. Long-term change in tidal dynamics and its cause in the Pearl River Delta, China. Geomorphology 120, 209-223 (2010).

[100] Brunier, G., Anthony, E. J., Goichot, M., Provansal, M. \& Dussouillez, P. Recent morphological changes in the mekong and bassac river channels, 
mekong delta: The marked impact of river-bed mining and implications for delta destabilisation. Geomorphology 224, 177-191 (2014).

[101] Vermeulen, B., Hoitink, A. J. F. \& Labeur, R. J. Flow structure caused by a local cross-sectional area increase and curvature in a sharp river bend. Journal of Geophysical Research: Earth Surface 120, 1771-1783 (2015).

[102] Wolanski, E., King, B. \& Galloway, D. Dynamics of the turbidity maximum in the fly river estuary, papua new guinea. Estuarine, Coastal and Shelf Science 40, 321-337 (1995).

[103] Sassi, M. G., Hoitink, A. J. F., de Brye, B., Vermeulen, B. \& Deleersnijder, E. Tidal impact on the division of river discharge over distributary channels in the mahakam delta. Ocean Dynamics 61, 2211-2228 (2011).

[104] Bagnold, R. A. An approach to the sediment transport problem. General Physics Geological Survey, U.S. Geol. Surv. Prof. paper (1966). 37 p. 
Box 1 Morphological equilibrium in a tide-dominated delta.

A morphological equilibrium can be defined as a state in which erosion nor deposition occurs in a geophysical surface flow with active sediment transport. In a dynamic morphological equilibrium, erosion and deposition balance when averaged over a long enough time span. At any place in an equilibrium system, the gradient of the mean sediment transport vector balances the external sources and sinks. In a tide-dominated delta, the key elements controlling this balance can be considered from the following simplified, one-dimensional consideration. Assume the cross-section averaged channel flow velocity $\left(u_{t}\right)$ is composed of a constant residual flow component $u_{r}$, the dominant tidal harmonic with amplitude $U_{d}$, phase $\phi_{d}$ and angular frequency $\omega$, and an overtide representing tidal asymmetry, with amplitude $U_{o}$ and phase $\phi_{o}$ :

$$
u_{t}=u_{r}+U_{d} \cos \left(\omega t-\phi_{d}\right)+U_{o} \cos \left(2 \omega t-\phi_{o}\right)
$$

In a first order approximation, sediment transport in the channel $S_{r}$ can be considered proportional to $u_{t}^{3104}$ :

$$
S=a u_{t}^{3}
$$

The mean sediment transport at any location in the channel then proceeds from the average over a tidal cycle of period $T$ :

$$
S_{m}=\frac{1}{T} \int_{0}^{T} a u_{t}^{3} d t=\underbrace{a u_{r}^{3}}_{S_{r}}+\underbrace{\frac{3 a}{2}\left(u_{r} U_{d}^{2}+u_{r} U_{o}^{2}\right)}_{S_{r t}}+\underbrace{\frac{3 a}{4} U_{d}^{2} U_{o} \cos \left(\phi_{o}-2 \phi_{d}\right)}_{S_{t}}
$$


The three components contributing to $S_{m}$ are $S_{r}$, which is directed seaward and mainly controlled by the river discharge, $S_{r t}$, quantifying how tides enhance the sediment carrying capacity of the seaward residual flow and $S_{t}$, representing the transport by tidal asymmetry, typically directed inland. The tidal asymmetry term represents the contribution by differences in maximum velocities between ebb and flood, exerting a strong control on residual sediment transport during periods of low river discharge. During low river discharge, distributaries are typically flooddominant because of tidal asymmetry. $S_{t}$ then dominates over the sum of $S_{r}$ and $S_{r t}$, resulting in accumulation of sediment in the delta. High river discharges attenuate the tide, and cause the tidal flow cycle to become more symmetrical. The sum of $S_{r}$ and $S_{r t}$ then dominate over $S_{t}$, by which much of the sediment accumulated during low flow is washed out again. Under equilibrium conditions, the sediment import during periods of low-flow balances the export during high flows.
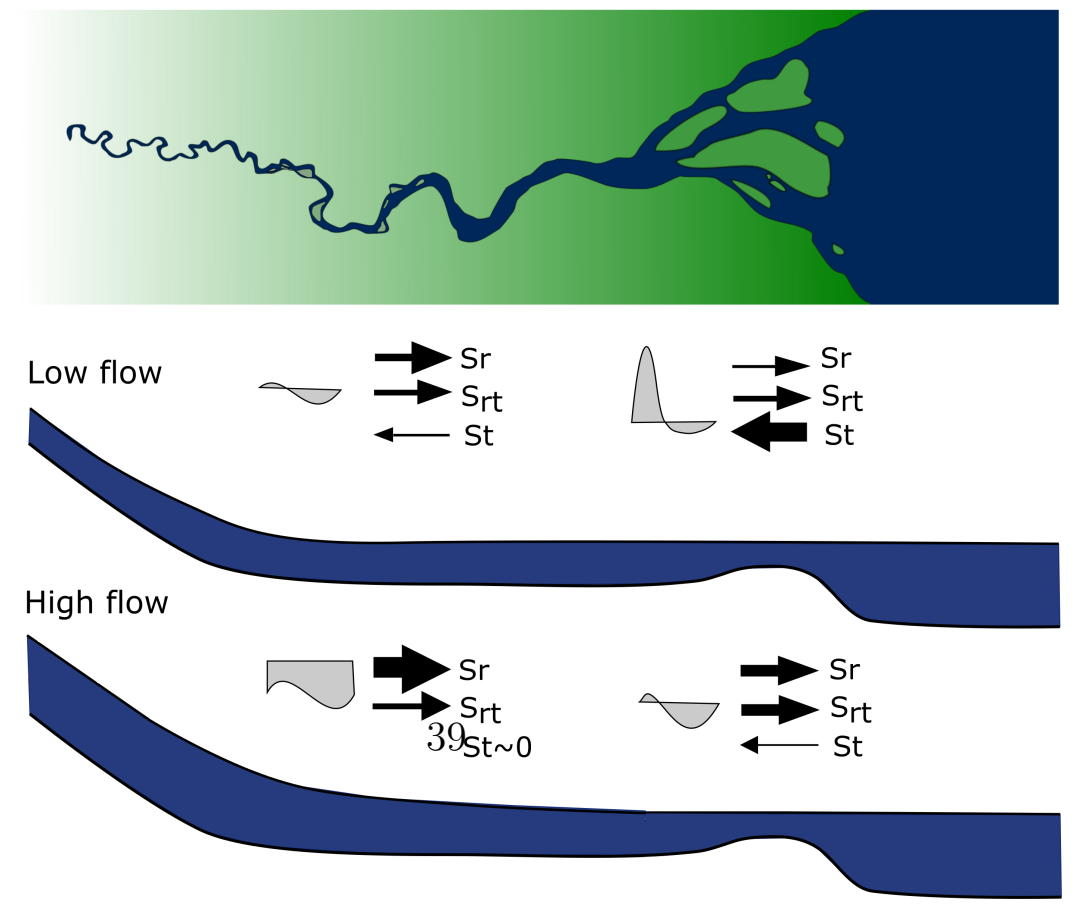


\section{List of Figures}

1 The river-dominated part in the planform of a delta can often readily be distinguished from the tide-dominated part. This is here illustrated for the Mahakam Delta in Indonesia ${ }^{25}$. The arc in the figure corresponds to a break in scaling behavior of channel depth, width and the ratio between tidal and fluvial discharges, which splits the distributary channels into parts where the river discharge dominates the channel morphology (dark blue) and parts where the tidal discharge is dominant (purple). Tidal meanders that receive insignificant river discharge are in red. . . . . . . . . . . . .

2 Trifurcations in the planform of a mouthbar complex indicate a strong tidal control on delta morphology. At the channel trifurcation, a distributary splits into a central channel where that seaward ebb flow is concentrated and two lateral channels, which are kept open by the flood flow in particular. Examples of trifurcations can be found from Landsat images of the Suwanee River mouth (top left), the Kapuas Delta (top rigth) and the Fly Delta (bottom right). The bottom right panel shows morphodynamic model simulations for increasing tidal amplitude $\left(h_{t}\right)^{32} \ldots \ldots \ldots$. . . . . . . 42

3 In a predefined modeling domain, subaqueous patterns of channels and shoals can be predicted. This is here illustrated for an idealized setting under combined river and tidal forcing ${ }^{50}$. The terminal estuarine morphology and residual sediment transport vectors are shown based on model simulations with an increasing river discharge $(Q)$. The morphology for zero discharge and an intermediate discharge shows characteristic ebb and flood channels. . . . . . . . . . .

4 Intertidal areas are generally elevated above the embanked hinterland, which is caused by deposition of marine sediment during high tide and storm surges. This is illustrated for the GangesBrahmaputra Delta (left) and the Rhine-Meuse Delta (right). The intertidal areas in the Ganges-Brahmaputre Delta are more flood resilient than the embanked areas ${ }^{8}$.

5 The construction of a storm surge barrier may result in unexpected morphological developments. After closure of the Haringvliet Basin in 1970, incision took place in the Old Meuse ${ }^{98}$. The bottom panels show the development of a recent scour hole over a period of 5 years, at the location indicated with a red dot. . . . . . . . . . 45 


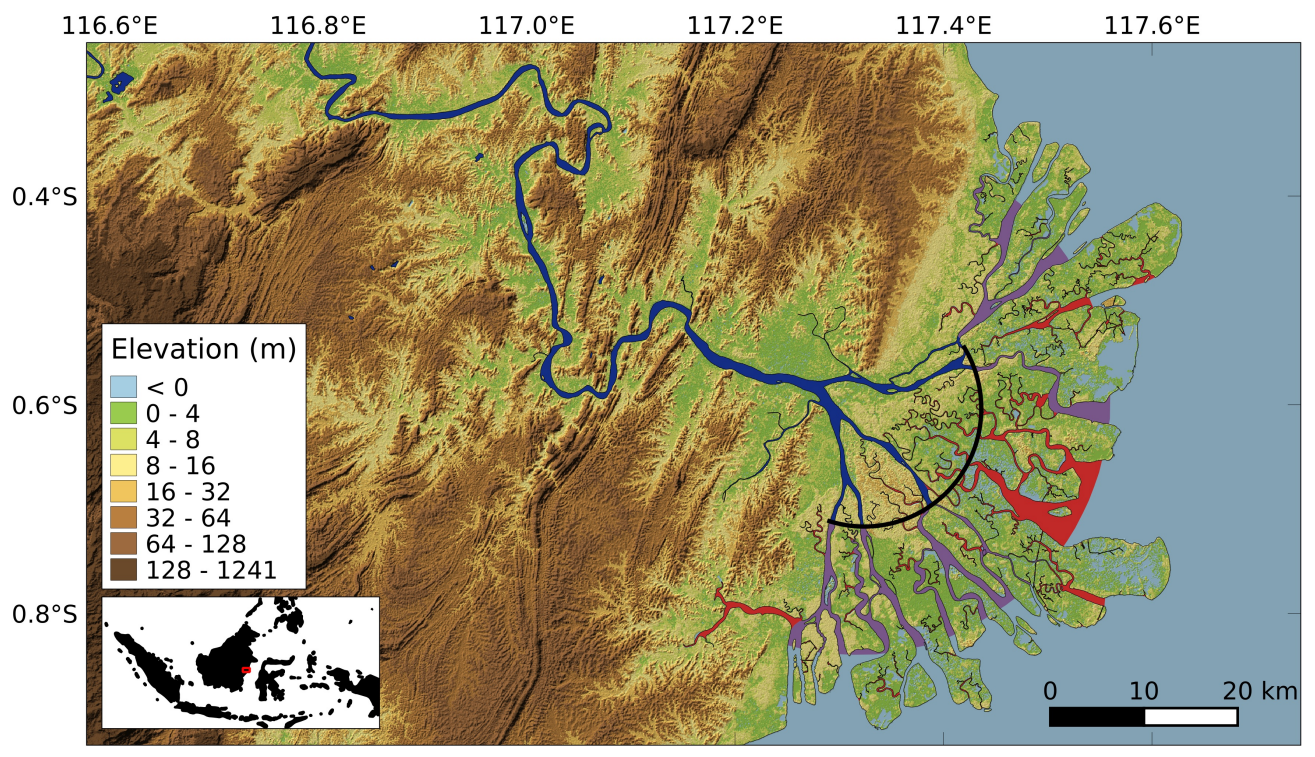

Figure 1: The river-dominated part in the planform of a delta can often readily be distinguished from the tide-dominated part. This is here illustrated for the Mahakam Delta in Indonesia ${ }^{25}$. The arc in the figure corresponds to a break in scaling behavior of channel depth, width and the ratio between tidal and fluvial discharges, which splits the distributary channels into parts where the river discharge dominates the channel morphology (dark blue) and parts where the tidal discharge is dominant (purple). Tidal meanders that receive insignificant river discharge are in red. 


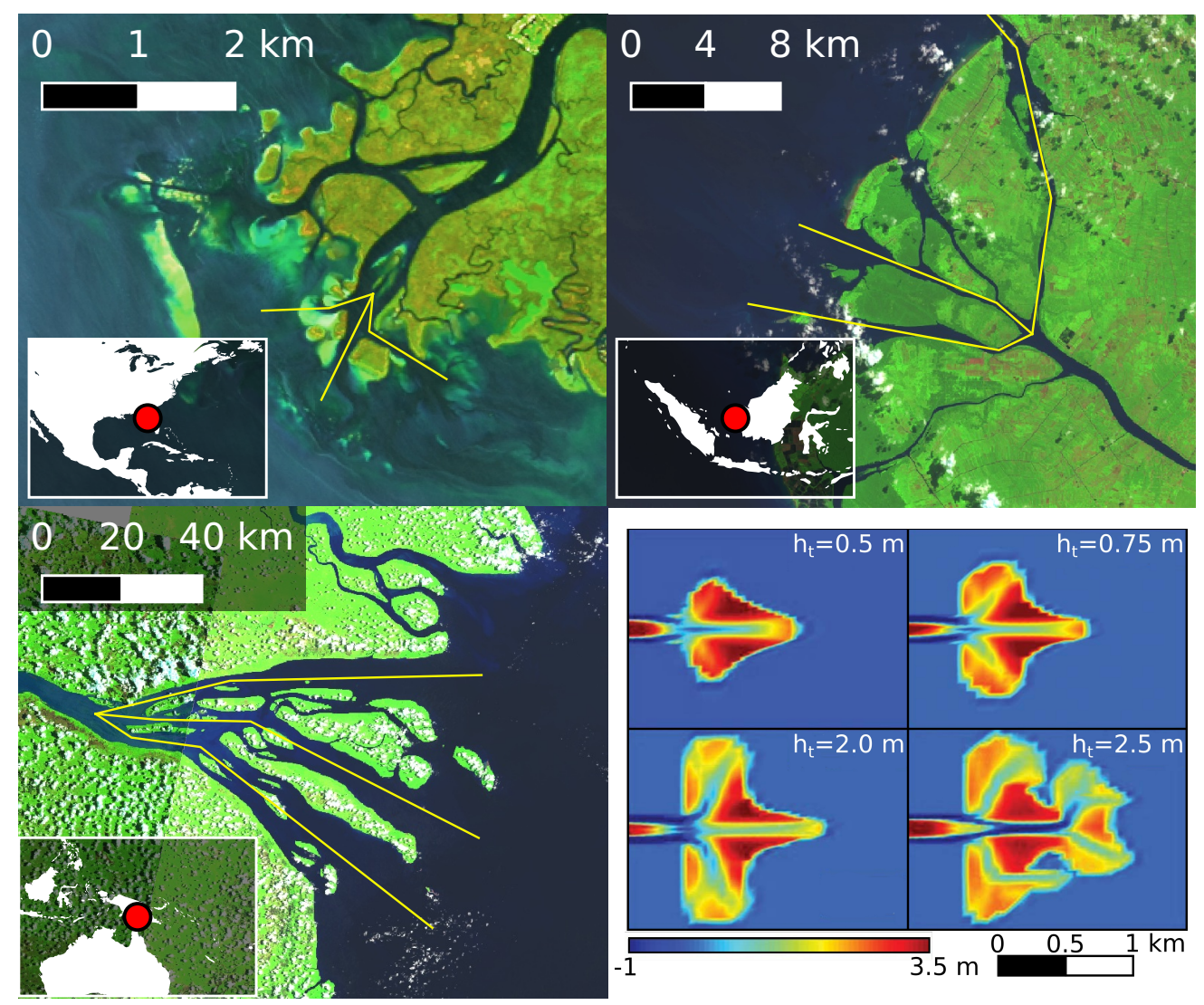

Figure 2: Trifurcations in the planform of a mouthbar complex indicate a strong tidal control on delta morphology. At the channel trifurcation, a distributary splits into a central channel where that seaward ebb flow is concentrated and two lateral channels, which are kept open by the flood flow in particular. Examples of trifurcations can be found from Landsat images of the Suwanee River mouth (top left), the Kapuas Delta (top rigth) and the Fly Delta (bottom right). The bottom right panel shows morphodynamic model simulations for increasing tidal amplitude $\left(h_{t}\right)^{32}$. 


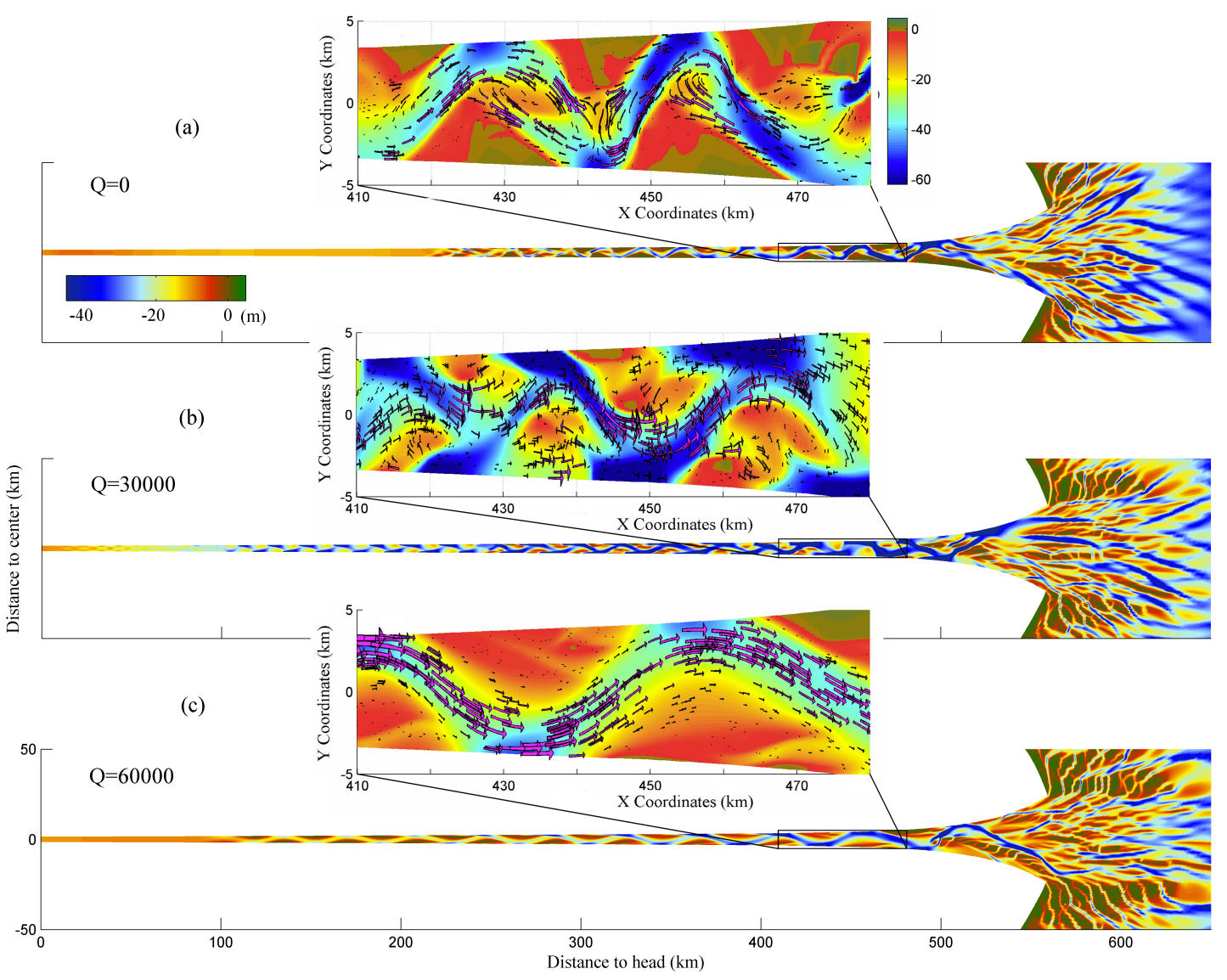

Figure 3: In a predefined modeling domain, subaqueous patterns of channels and shoals can be predicted. This is here illustrated for an idealized setting under combined river and tidal forcing ${ }^{50}$. The terminal estuarine morphology and residual sediment transport vectors are shown based on model simulations with an increasing river discharge $(Q)$. The morphology for zero discharge and an intermediate discharge shows characteristic ebb and flood channels. 

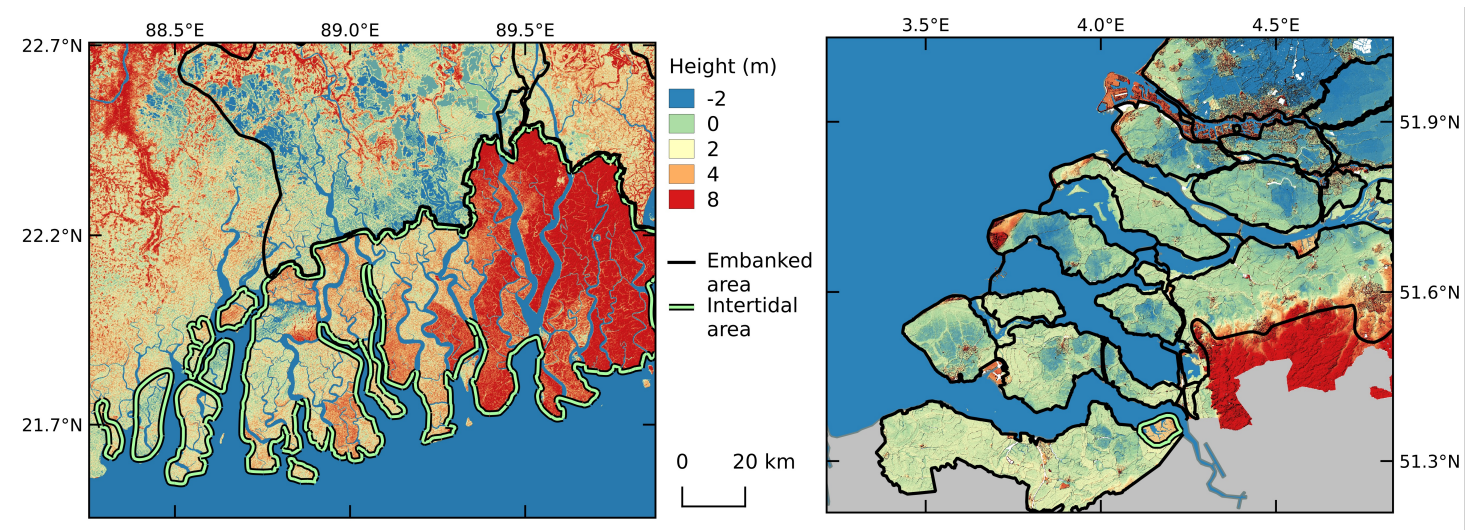

Figure 4: Intertidal areas are generally elevated above the embanked hinterland, which is caused by deposition of marine sediment during high tide and storm surges. This is illustrated for the Ganges-Brahmaputra Delta (left) and the RhineMeuse Delta (right). The intertidal areas in the Ganges-Brahmaputre Delta are more flood resilient than the embanked areas ${ }^{8}$. 


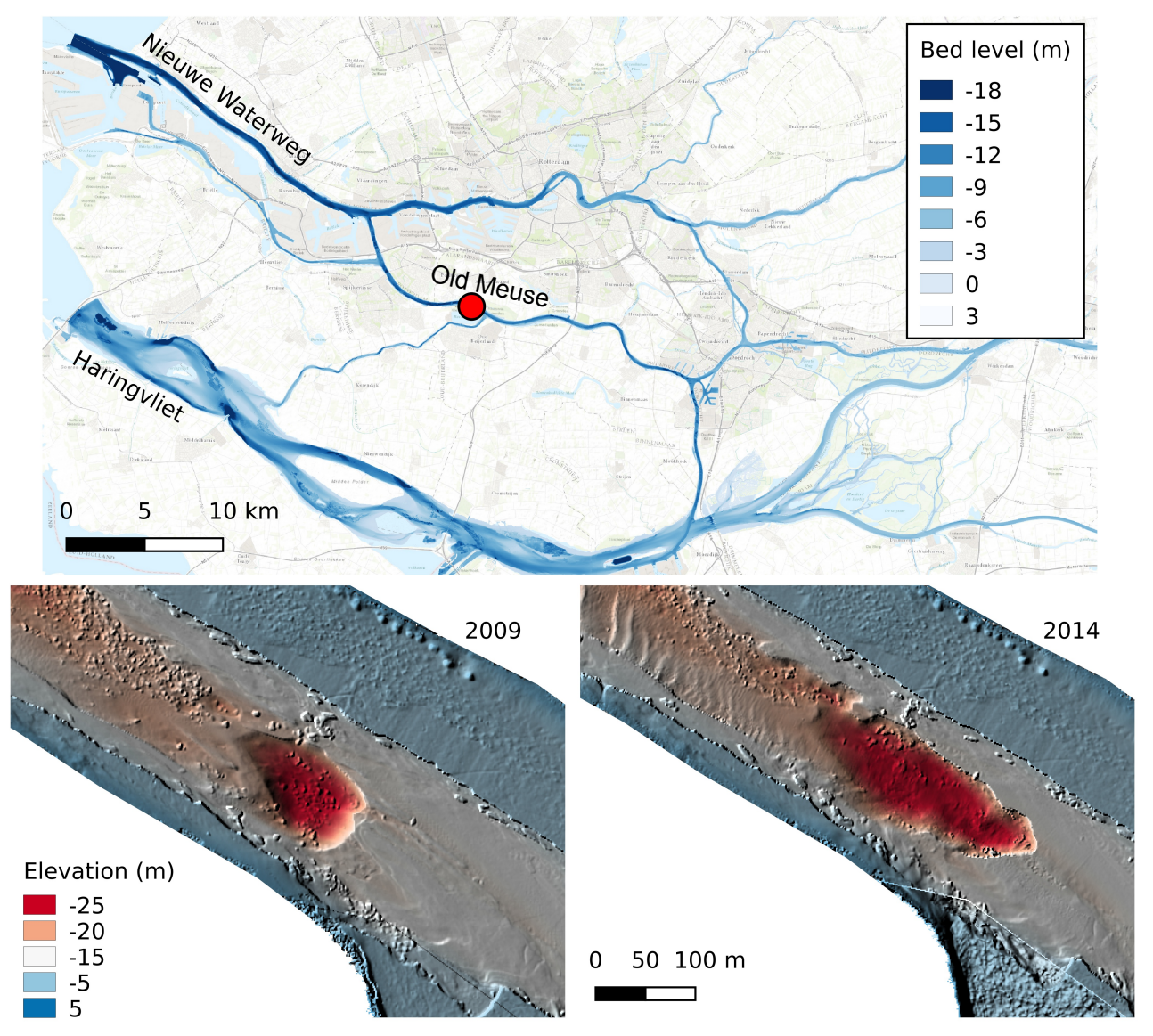

Figure 5: The construction of a storm surge barrier may result in unexpected morphological developments. After closure of the Haringvliet Basin in 1970, incision took place in the Old Meuse ${ }^{98}$. The bottom panels show the development of a recent scour hole over a period of 5 years, at the location indicated with a red dot. 